\title{
Manajemen Soft skills Guru dalam Menguatkan Mutu Pembelajaran di PAUD
}

\author{
Upik Elok Endang Rasmani ${ }^{\circledR}{ }^{凶}$, Anayanti Rahmawati ${ }^{1}$, Warananingtyas Palupi ${ }^{1}$, \\ Jumiatmoko1, Nurul Shofiatin Zuhro1, Anjar Fitrianingtyas' \\ Pendidikan Guru Pendidikan Anak Usia Dini, Universitas Sebelas Maret, Indonesia(1) \\ DOI: $\underline{10.31004 / o b s e s i . v 6 i 2.1584}$
}

\begin{abstract}
Abstrak
Kualitas lembaga PAUD menjadi faktor kunci bagi kualitas pendidikan bagi anak usia dini. Guru memiliki posisi strategis bagi pencapaian lembaga PAUD yang bermutu. Guru yang ideal harus memiliki kapasitas hard skills dan soft skills yang mumpuni. Penelitian ini bertujuan memberikan penguatan atas kemampuan soft skills guru PAUD untuk mendorong peningkatkan kualitas lembaga PAUD. Jenis penelitian yang dilakukan adalah penelitian deskriptif kualitatif. Penelitian ini dilaksanakan selama 7 bulan pada sebuah TK Swasta Unggulan di Surakarta. Teknik pengumpulan data menggunakan observasi, wawancara, dan kuesioner. Partisipan yang bersedia terlibat dalam penelitian ini sebanyak 16 orang. Hasil penelitian menunjukkan bahwa faktor utama tercapainya kualitas lembaga PAUD berasal dari kompetensi soft skills guru, meliputi kompetensi pedagogik, kepribadian, maupun profesionalitas. Oleh karena itu, sangat diperlukannya manajemen soft skills bagi guru PAUD. Manajemen Soft Skills berdampak pada peningkatan kemampuan soft skills guru dan kualitas lembaga PAUD.
\end{abstract}

Kata Kunci: kualitas lembaga paud; manajemen soft skills; guru paud

\begin{abstract}
The quality of PAUD institutions is a key factor for the quality of early childhood education. Teachers have a strategic position for the achievement of quality PAUD institutions. The ideal teacher must have a strong capacity for hard skills and soft skills. This study aims to strengthen the soft skills of PAUD teachers to encourage the improvement of the quality of PAUD institutions. The type of research conducted is descriptive qualitative research. This research was carried out for 7 months at a Superior Private Kindergarten in Surakarta. Data collection techniques using observation, interviews, and questionnaires. There were 16 participants who were willing to be involved in this study. The results of the study indicate that the main factor in achieving the quality of PAUD institutions comes from the soft skills of teachers, including pedagogic competence, personality, and professionalism. Therefore, it is very necessary for the management of soft skills for PAUD teachers. Soft Skills Management has an impact on improving the soft skills of teachers and the quality of PAUD institutions.
\end{abstract}

Keywords: quality of paud institutions; soft skills management; paud teacher

Copyright (c) 2021 Upik Elok Endang Rasmani, et al.

$\triangle$ Corresponding author : upikelok@staff.uns.ac.id (Jalan Slamet Riyadi No. 449, Pajang, Surakarta)

Received 26 February 2021, Accepted 16 July 2021, Published 22 July 2021 


\section{PENDAHULUAN}

Pembangunan nasional dalam tinjauan pendidikan adalah sebuah upaya untuk mencerdaskan kehidupan bangsa dan meningkatkan kualitas sumber daya manusia (Yusutria, 2017), yang beriman (Yusutria, 2018), bertakwa, memiliki akhlak dan budi pekerti mulia serta memiliki penguasaan terhadap berbagai ilmu pengetahuan, teknologi, dan juga seni yang bertujuan untuk menjadikan masyarakat yang maju, adil, makmur serta beradab (Kemendikbud, 2020). Upaya mencerdaskan kehidupan bangsa harus dimulai dengan pendidikan sejak usia dini. Pendidikan anak pada usia dini berperan penting dikarenakan ketika anak berusia 0 - 6 tahun merupakan masa peka atau masa emas anak (Alwi, Ramadani, Suhanir, Safira, \& Herma, 2018).

Salah satu upaya untuk meningkatkan mutu pendidikan adalah dengan meningkatkan kualitas lembaga pendidikan. Dalam upaya peningkatan kualitas lembaga PAUD tidak hanya melakukan pemenuhan pada aspek input dan output saja, namun yang lebih penting adalah aspek proses. Dimulai dari pengambilan sebuah keputusan, pengelolaan program yang direncanakan, proses pengelolaan, proses kegiatan belajar mengajar dan proses untuk monitoring serta evaluasi. Dalam konteks ini, prose pembelajaran memiliki tingkat signifikasi yang tertinggi jika dibandingkan dengan proses lainnya (Sum \& Taran, 2020). Keberhasilan proses pembelajaran senantiasa terikat erat dengan kualitas guru sebagai aktor utamanya. Oleh karena itu, diperlukan seorang guru yang mumpuni dalam upaya meningkatkan kualitas lembaga.

Berbicara mengenai kompetensi guru, sesungguhnya tidak hanya dilihat dari segi kualifikasi pendidikannya. Lebih dari itu, soft skills dalam diri guru juga sangat menentukan ukuran kompetensi seorang guru. Kesuksesan yang dicapai seseorang guru tidak hanya ditentukan oleh faktor pengetahuan atau keterampilan teknis (hard skills), akan tetapi justru ditentukan dari keterampilan dalam pengelolaan diri serta orang lain (soft skills) (Yuniendel, 2018). Hal tersebut diperkuat sebuah buku dengan judul "Lesson From The Top" yang ditulis Neff dan Citrin (Muhmin, 2018), dalam buku tersebut dituliskan sharing dan wawancara terhadap 50 orang yang dikategorikan tersukses di Amerika. Mereka berpendapat bahwa hal yang paling menentukan kesuksesan tidak hanya berasal dari keterampilan teknis melainkan terletak pada keterampilan soft skills (kualitas diri yang termasuk keterampilan yang berhubungan dengan orang sekitar atau people skills).

Penelitian terkait kompetensi guru telah banyak dilaksanakan guna mendorong terjadinya peningkatan soft skills tertentu bagi guru. Upaya pelatihan dilaksanakan dengan menyasar pada komponen komptensi tertentu misalnya pembuatan media pembelajaran inovatif (Astriani \& Alfahnum, 2020) dan penggunaan ICT (Putri, Suryati, Kartini, \& ..., 2020) dalam pembelajaran. Studi yang secara spesifik menguraikan manajemen soft skills bagi guru PAUD belum pernah dilaksanakan. Fakta di lapangan menunjukkan bahwa proses pendidikan pada salah satu TK Swasta Unggulan di Surakarta diselenggarakan hanya mengandalkan kemampuan teknis saja (hard skills) guru sedangkan soft skills tidak menjadi prioritas. Sehingga keberhasilan pencapaian mutu lembaga hanya di peroleh dari nilai (secara kuantitas) bukan secara kualitas. Oleh karena itu tujuan dalam penelitian yang dilakukan ini adalah untuk meningkatkan manajemen soft skills guru PAUD agar dapat mendorong peningkatan kualitas lembaga PAUD. Urgensi dari penelitian ini adalah diperlukannya penguatan manajemen soft skills bagi guru PAUD sehingga berdampak pada peningkatan kualitas lembaga PAUD dan memberikan dampak secara langsung bagi guru untuk menjadi guru yang baik, dapat mengoptimalkan kemampuan soft skills seperti komunikasi, interpersonal, membangun tim, berpikir kritis, sikap positif, menjalin hubungan dengan peserta didiknya dengan orang tua maupun masyarakat.

\section{METODOLOGI}

Jenis penelitian yang dilakukan adalah penelitian deskriptif kualitatif. Langkah awal dimulai dengan studi atau kajian literatur tentang kualitas lembaga PAUD yaitu bagaimana 
manajemen soft skills guru PAUD. Studi literatur berupa pengumpulan data baik dari buku maupun jurnal. Penelitian ini dilaksanakan selama 7 bulan pada TK Swasta Unggulan di Surakarta. Teknik pengumpulan data dengan observasi, wawancara, dan kuesioner secara langsung kepada guru. Selanjutnya data setelah berhasil dikumpulkan dilakukan analisis data. Data dianalisis menggunakan analisis data interkatif Miles, Huberman, dan Saldana (2012). Proses analisis data dilanjutkan dengan membandingkan hasil penelitian dengan fakta yang ditemukan di lapangan serta membandingkannya dengan implementasi yang sudah dilaksanakan.

Sampel dipilih secara Purposive dan yang bersedia terlibat sebanyak 16 (enam belas) responden. Metode pengumpulan data dilakukan dengan menggunakan data primer (data dari hasil penelitian, dapat berupa data hasil observasi dan melakukan wawancara langsung pada guru di lokasi serta data hasil pemberian kuesioner) dan data sekunder (data yang berupa jurnal maupun buku yang digunakan sebagai data tambahan dalam analisis data). Secara umum alur pelaksanaan penelitian ini dipaparkan dalam gambar 1.

Studi literatur (pengumpulan data, buku dan jurnal yang berkaitan dengan kualitas lembaga PAUD dan manjemen soft skills guru PAUD

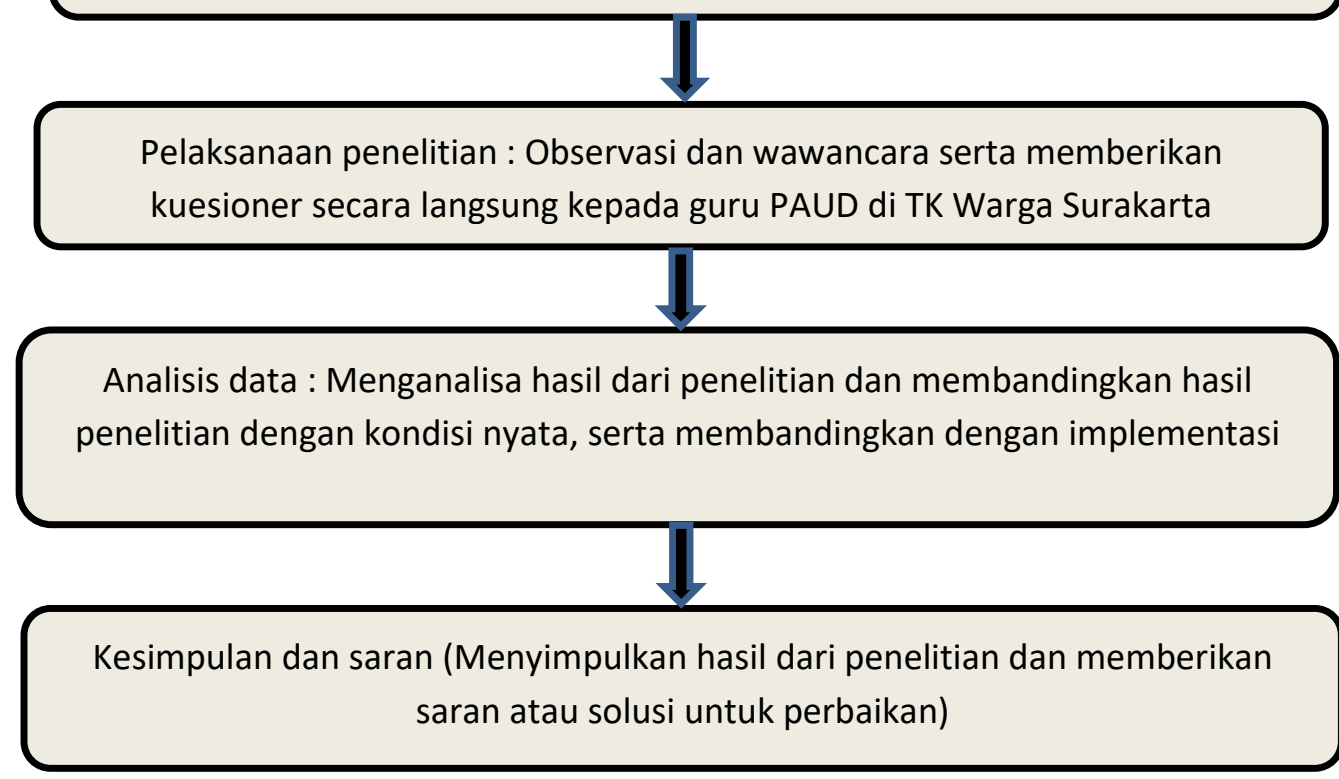

Gambar 1. Diagram Alur Penelitian

\section{HASIL DAN PEMBAHASAN}

\section{Kualitas Lembaga PAUD}

Pendidikan anak usia dini adalah usaha pembinaan yang diberikan pada anak usia dari usia lahir hingga berusia enam tahun yang bertujuan untuk membantu memberikan stimulus terhadap pertumbuhan dan perkembangan anak, baik lingkup jasmani maupun rohani sehingga pada akhirnya anak diperoleh kesiapan untuk memasuki jenjang pendidikan yang lebih tinggi (“Undang-Undang Republik Indonesia Nomor 20 tentang Sistem Pendidikan Nasional," 2003). Pendidikan anak usia dini merupakan fondasi yang paling mendasar bagi pembentukan tumbuh kembang dan kepribadian anak pada suatu saat kelak. Usia dini adalah waktu terpenting dan tidak akan terulang kembali dalam pembentukan aspek pertumbuhan dan perkembangan anak selama kehidupannya (Agustina \& Mukarromah, 2021).

Kondisi atau kualitas pendidikan suatu lembaga PAUD memberikan pengaruh terhadap keberhasilan selama keberjalanannya, berpengaruh bagi penyelenggaraan PAUD pada masa depan, dan juga dapat memberikan pengaruh pada proses perkembangan dan pertumbuhan anak. Elliott (2006) dalam bukunya yang berjudul "Early Childhood Education 
Pathway to Quality and Equity for All Children" menjelaskan bahwa PAUD yang berkualitas dapat memberikan pengaruh pada perkembangan sosial, kognitif, dan kemampuan anak dalam proses adaptasi di lingkungan tempat sekolahnya. Dalam bukunya tersebut dinyatakan bahwa anak yang menempuh pendidikan di lembaga PAUD akan memiliki perbedaan yakni terletak pada kemampuan kognitif yang lebih baik jika dibandingkan dengan anak-anak yang tidak menempuh. Kemampuan anak tersebut dikatakan memiliki hubungan yang kuat dengan tingkat kualitas dari lembaga PAUD didalamnya. Sebab itu, sangat penting dalam sebuah lembaga PAUD untuk dapat memperhatikan kualitas pendidikan dari lembaga PAUD, sehingga kedepannya dapat membentuk peserta didik yang unggul dari segi atau aspek pertumbuhan dan perkembangannya.

\section{Manajemen Soft skills Guru PAUD}

Berdasarkan Permendikbud No. 137 Tahun 2014 pendidik anak usia dini terdiri dari guru PAUD, guru pendamping, dan guru pendampingan muda. Pendidik anak usia dini merupakan tenaga profesional yang memiliki tugas untuk merencanakan, melaksanakan, dan menilai hasil pembelajaran, serta melakukan pembimbingan, pelatihan, pengasuhan, dan perlindungan. Awal pembangunan manusia yang berkualitas ddimulai sejak Pendidikan Anak Usia Dini, oleh karena itu Guru PAUD sebagai tenaga pendidik anak usia dini sudah seharusnya diberikan pegangan berupa kompetensi yang mumpuni agar memiliki kemampuan dalam memberikan pengajaran yang sesuai dengan tuntutan perkembangan pembelajaran dalam Pendidikan Anak Usia Dini pada zaman sekarang. Guru PAUD sebagai pendidik dituntut untuk mempunyai keahlian khusus sebelum mentransformasikan pada anak didik. Sehingga dengan begitu para pendidik diharapkan mampu untuk berkompetisi terutama pada era revolusi industri 4.0. (Robbie \& Marsudi, 2021).

Pendidik dikatakan sebagai prioritas pertama dalam rangka mewujudkan keberhasilan pada sebuah pendidikan, oleh sebab itu guna menyesuaikan kemajuan zaman yang serba cepat dan canggih maka diperlukan segenap guru yang selalu berusaha meningkatkan presentase kualitasnya sehingga dapat menyelaraskan antara pengetahuan dengan tuntutan zaman. Setiap pendidik yang professional akan sangat diharapkan memiliki bilah pedang berupa kompetensi dan penguasaan yang mendalam dalam setiap bidangnya. Penguasaan pengetahuan inilah yang akan menjadi tolak ukur penting selain keterampilan yang lainnya (Sum \& Taran, 2020). Pembinaan pendidik dalam kaitannya dengan peningkatan keterampilan atau kompetensi profesi keguruan dalam sebuah lembaga PAUD yang sesuai dengan pertumbuhan anak sangat perlu dilakukan. Kompetensi guru sebagai pendidik tidak dapat jika hanya dilihat dari kualifikasi pendidikannya saja, namun soft skills dalam diri guru juga sangat menentukan.

Rao dan Diakiw (2019) memberikan penjelasannya tentang soft skill yaitu cara yang sopan dan menyenangkan untuk menunjukkan kepada orang lain dan sebagian besar terkait dengan kepribadian, sikap dan perilaku. Lebih jauh lagi soft skill digambarkan sebagai kumpulan keterampilan dan kemampuan yang relevan dengan komunikasi, mengatur waktu, pemecahan masalah, negosiasi, menulis, mendengarkan, membaca, dan pengambilan keputusan. Selain itu, softs skills juga meliputi kemampuan untuk menyelesaikan tugas, pengaturan diri, kesadaran diri, mengembangkan dan memelihara hubungan positif dan interaksi positif dan sehat dengan teman sebaya dan orang dewasa.

Selama beberapa dekade terakhir di dalam masyarakat, pendapat tentang soft skill telah banyak berubah. Pada zaman dulu penguasaan hard skill dinilai pertama dan soft skill dianggap "bagus untuk dimiliki", persepsinya terbalik. Keterampilan komunikasi yang baik dapat dengan mudah digunakan untuk menutupi kekurangan dalam hard skill. Saat ini secara umum, orang yang ekstrovert, yang pandai memasarkan diri, dan mudah bersosialisasi akan dinilai lebih unggul daripada orang lain yang tidak memiliki atribut tersebut. Teknisi tua yang baik, jagoan di bidangnya, tetapi menjadi tertutup dan berbicara kurang dari sepuluh kalimat lengkap sehari tidak lagi dihargai. Soft skill memainkan peran penting dalam membentuk 
kepribadian seseorang, mereka memungkinkan kompetensi sosial, dan mereka melengkapi hard skill, yang merupakan persyaratan teknis suatu pekerjaan. Dengan demikian, soft skill dikatakan tidak kalah pentingnya dengan hard skill, akan tetapi tidak boleh disalahgunakan untuk tujuan menyamarkan kurangnya keahlian seseorang di bidang tertentu (Hassan et al., 2013).

Fakta dilapangan pada saat peneliti melakukan observasi dan wawancara didapati rendahnya kualitas kemampuan yang tertanam dalam diri tenaga pendidik anak usia dini, dimana guru masih kaku dalam proses pelaksanaan pendidikan dan pembelajaran, dan hanya menekankan pada kemampuan membaca, menulis, dan berhitung. Di sisi lain kemampuan hard skill guru lebih tinggi dibandingkan dengan kemampuan soft skill guru seperti kemampuan komunikasi baik lisan dan tulisan masih belum berkembang dengan baik. Hal ini dibuktikan dengan guru pada saat mengajar masih menggunakan cara yang lama yaitu mengajarkan kepada anak dengan tergesa-gesa dengan tujuan supaya anak lebih cepat paham terhadap materi yang diberikan, serta kurangnya motivasi guru dalam mengajar sehingga guru belum bisa memberikan motivasi yang lebih terhadap anak didiknya. Hal ini bertolak belakang dengan model pembelajaran yang harus diterapkan pada Pendidikan Anak Usia Dini yaitu dengan pembelajaran berbasis kan bermain dan belajar dengan pendekatan kepada anak secara cara halus dan tanpa adanya pemaksaan (Khoeroni \& Tengah, 2018), dan menunjukkan bahwa guru belum bisa memberikan etos kerja yang baik dalam memberikan motivasi kepada anak didik.

Fakta lain ditemukan oleh peneliti pada saat melakukan pengumpulan data terkait kemampuan soft skill guru. Didapati hasil bahwa kemampuan soft skill guru masih kurang, ditunjukkan dengan sikap kurangnya komunikasi antara guru dengan rekan yang lain. Seperti kurangnya koordinasi dalam guru memberikan arahan maupun informasi kepada orang tua murid sehingga menimbulkan persepsi yang berbeda antara guru yang satu dengan guru yang lain. Selain itu rendahnya kemampuan guru dalam mengatur waktu antara kegiatan di sekolah maupun kegiatan di rumah menjadi satu permasalahan dalam meningkatkan kualitas lembaga PAUD khususnya dalam hal kemampuan soft skill yang dimiliki oleh guru. Fakta ini menunjukkan bahwa kemampuan soft skill guru di taman kanakkanak tersebut masih kurang sehingga perlu adanya tindakan secara khusus berupa pelatihan maupun kesadaran dari masing-masing guru untuk meningkatkan kemampuan soft skill pribadinya.

Sofia \& Yulista (2020) menyebutkan bahwa didalam kompetensi kepribadian guru memiliki indikator, yaitu antara lain meliputi; memiliki jiwa pendidik, berperilaku sesuai norma agama (guru hendaknya memliki kepribadian yang sesuai dengan pedoman nilai dan norma yang berlaku, yaitu guru yang mampu memberikan berbagai alternatif solusi terhadap permasalahan, mampu untuk mengendalikan diri, dan bertanggung jawab dalam hal mendidik), sosial dan budaya, hukum; menjadi pribadi yang selalu mengutakaman kejujuran, memiliki budi pekerti yang mulia, dan dapat dijadikan sebagai teladan (role model) bagi peserta didiknya. Hasil penelitian Arisman dkk (dalam Sofia \& Yulista, 2020) menyatakan bahwa kompetensi kepribadian yang dimiliki guru dan motivasi kerja, memiliki pengaruh terhadap motivasi belajar siswa. Kemudian hasil penelitian yang dilakukan Sukamto \& Pardjono (2017) menunjukkan bahwa kompetensi guru memberikan pengaruh yang positif serta cenderung signifikan terhadap kinerja yang dimiliki oleh guru.

Untuk meningkatkan kemampuan soft skill guru PAUD harus berlandaskan pada penguatan dasar-dasar ke-PAUD-an, seperti dalam ruang lingkup PAUD, terkait perkembangan anak, bermain sebagai media utama belajar anak, pemberdayaan potensi dan kearifan lokal daerah (Yusutria, 2017) yang terdapat di dalam manajemen soft skill guru PAUD. Hal-hal tersebut dilakukan oleh peneliti melalui kegiatan berupa diskusi maupun memberikan informasi terkait dengan webinar-webinar untuk meningkatkan kemampuan soft skill guru PAUD. Selama kegiatan diskusi peneliti memaparkan hal-hal yang perlu ditingkatkan yaitu dalam hal kemampuan soft skill guru PAUD dalam hal etika 
keprofesionalan di mana guru harus saling bekerja sama dalam meningkatkan kualitas lembaga PAUD dibuktikan dengan kegiatan bersama-sama merencanakan program tahunan, program semester, RPPM, RPPH, sehingga semua guru dapat berperan aktif dan saling bekerja sama satu dengan yang lainnya.

Peningkatan manajemen soft skill juga dilakukan oleh peneliti dengan memberikan arahan kepada guru terkait pandangan mengenai kemampuan soft skill yang dimilikinya (Lisnawati, 2018). Manajemen soft skill merupakan suatu kemampuan mengatur kemampuan soft skill yang dimiliki oleh guru untuk menentukan arah pemanfaatan hard skill yang dimilikinya (Thuneberg, Salmi, \& Bogner, 2018). Dalam artian jika guru memiliki ilmu maupun keterampilan dengan baik maka akan mendatangkan kenyamanan dan kesejahteraan bagi orang-orang di sekitarnya Jika seorang guru tidak memiliki soft skill yang baik maka kemampuan hard skill yang dimilikinya dapat membahayakan dirinya dan orang lain (Sumiyati, 2020) contoh ketika seorang guru memiliki kemampuan soft skill berkomunikasi maka dalam proses pembelajaran guru perlu mengembangkan kerjasama dengan guru yang lain dalam menyusun konsep pembelajaran yang cocok dengan pendidikan anak usia dini sehingga ilmu yang diberikan dapat mengembangkan aspek perkembangan yang dimiliki oleh anak secara maksimal.

Peneliti juga memberikan pelatihan kepada guru dan kepala sekolah dalam merancang perangkat pembelajaran yang sesuai dengan karakteristik anak usia dini yang kreatif dan inovatif. Pelatihan berupa pemberian materi terkait pembuatan video maupun materi pembelajaran menggunakan program komputer seperti PowerPoint. Hal ini mendorong guru untuk mengembangkan kemampuan sosial yang dimilikinya. Dimana guru memiliki komitmen dan tekad yang kuat dalam mengembangkan pembelajaran pada pendidikan anak usia dini. Selain itu guru juga dituntut untuk mengembangkan kemampuan dalam mengakses dan mengolah data guna meningkatkan perkembangan kemampuan yang dimiliki oleh anak (Luo, Berson, Berson, \& Li, 2021). Disisi lain guru juga dilatih untuk dapat membuat publikasi ilmiah berupa buku maupun jurnal yang dapat digunakan sebagai referensi dalam mengembangkan kemampuan penulisan yang dimiliki oleh guru sehingga dapat meningkatkan pengembangan keprofesionalan yang dimiliki.

Profesionalisme guru sudah seharusnya dikembangkan sesuai dengan perkembangan zaman (ilmu pengetahuan, teknologi dan kebutuhan masyarakat) termasuk pada sumber daya manusia berkualitas yang sangat dibutuhkan dan memiliki kemampuan bersaing yang baik dalam berbagai kancah forum. Guru dikatakan sebagai "the front linear" nya dalam rangka usaha atau upaya peningkatan mutu pendidikan nasional. Demikian juga guru merupakan salah satu faktor yang menentukan keberhasilan atau kegagalan sebuah usaha peningkatan inovasi dan kualitas dalam lingkup pendidikan dalam tingkat sekolah (Sutarmanto, 2019). Guru yang profesional kedepannya akan tercermin dalam pelaksanaan tugas sebagai pendidik yang dapat dilihat dan ditandai dengan keahlian baik dalam penguasaan materi ataupun metode yang dimiliki. Guru profesional hendaknya mampu dan dapat memikul serta bertanggung jawab sebagai guru terhadap siswa, orang tua, masyarakat luas, bangsa, negara, serta agama secara penuh. (Febrialismanto, 2017).

Setelah peneliti melaksanakan diskusi dan pendekatan serta pemberian informasi terkait dengan webinar pengembangan kemampuan soft skill untuk guru Pendidikan Anak Usia Dini, serta pendampingan terkait manajemen soft skill, didapat hasil bahwa kemampuan soft skill guru Pendidikan Anak Usia Dini di TK tersebut mengalami peningkatan. Hal ini dibuktikan dengan kemampuan guru dalam berkomunikasi antara guru yang satu dengan yang lain sudah terjalin dengan baik di mana guru saling bekerja sama khususnya dalam menyusun pembelajaran yang baik untuk anak usia dini di masa sekarang. Selain itu komunikasi dengan orang tua juga terjalin dengan baik dibuktikan dengan guru senantiasa intensif dalam melihat perkembangan anak dan berkomunikasi dengan orang tua terkait perkembangan anak didik. Kegiatan monitoring dan evaluasi juga dilakukan oleh peneliti untuk melihat Bagaimana perkembangan kemampuan soft skill guru di TK tersebut. Beberapa 
hal tersebut diharapkan mampu memperkuat kualitas keprofesian pendidik atau kemampuan soft skills guru PAUD yang akhirnya dapat memberikan pengaruh positif terhadap peningkatan variasi pelaksanaan pembelajaran sehingga kedepannya dapat meningkatkan kualitas sebuah Lembaga PAUD.

\section{SIMPULAN}

Manajemen soft skill sangat penting bagi guru PAUD sehingga akan memberikan dampak pada peningkatan kualitas lembaga PAUD serta dapat memberikan dampak secara langsung bagi guru. Demi menunjang pencapaian mutu lembaga, guru seharusnya senantiasa mengasah dan mengoptimalkan soft skills yang dimiliki. Diantaranya kemampuan berkomunikasi, interpersonal, membangun tim, berpikir kritis, sikap positif, menjalin hubungan dengan peserta didik, orang tua maupun masyarakat. Pada penelitian yang akan datang, diperlukan adanya penelaahan secara lanjut terkait manajemen soft skills bagi guru dengan berbagai latar belakang individu maupun lembaga dalam rangka meningkatkan mutu pendidikan PAUD.

\section{UCAPAN TERIMA KASIH}

Terima kasih kepada LPPM UNS atas dukungan pembiayaan penelitian ini melalui skema Hibah Riset Grup Manajemen PAUD Tahun 2021 dan kepada keluarga besar program studi PG-PAUD UNS Surakarta atas dukungan moral maupun material kepada segenap tim peneliti.

\section{DAFTAR PUSTAKA}

Agustina, P., \& Mukarromah, T. T. (2021). Efektivitas Teknik Modifikasi Perilaku Token. Jurnal Ceria (Cerdas Energik Responsif Inovatif Adaptif), 4(3), 235-241.

Alwi, B. M., Ramadani, S., Suhanir, S., Safira, Z., \& Herma, T. (2018). Manajemen Peserta Didik Pada Taman Pendidikan Anak Usia Dini Do'a Ibu. NANAEKE: Indonesian Journal of Early Childhood Education, 1(1), 53. https:// doi.org/10.24252/nananeke.v1i1.6906

Astriani, M. M., \& Alfahnum, M. A. (2020). Peningkatan Kompetensi Guru PAUD dalam Mengembangkan Media Pembelajaran Inovatif. Jurnal PkM Pengabdian Kepada Masyarakat, 3(4), 366. https:// doi.org/10.30998/jurnalpkm.v3i4.8151

Elliott, A. (2006). Early Childhood Education: Pathways to Quality and Equity for All Children. In Australian Council for Education Research.

Febrialismanto. (2017). Kompentensi Profesional, Guru Pg Paud Kabupaten Kampar Provinsi Riau. Jurnal Pendidikan Anak, 6(2), 121-136. https://doi.org/10.21831/jpa.v6i2.17700

Hassan, A., Maharoff, M., Zainal Abiddin, N., SUPER, To, S., Progress, A. R., ... Yadav, A. (2013). Soft Skills Competency Tool for Secondary Teachers in Strengthening Effective. $\begin{array}{llll}\text { University of } \quad \text { Portland, } & \text { 146-155. }\end{array}$ https://doi.org/10.11114/jets.v2i3.455

Huberman, A., \& Miles, M. (2012). Understanding and Validity in Qualitative Research. In The Qualitative Researcher's Companion. https:// doi.org/10.4135/9781412986274.n2

Kemendikbud. (2020). Peraturan Menteri Pendidikan Dan Kebudayaan Republik Indonesia Nomor 19 Tahun 2020 tentang Perubahan atas Peraturan Menteri Pendidikan dan Kebudayaan Nomor 8 Tahun 2020 tentang Petunjuk Teknis Bantuan Operasional Sekolah Reguler. Jakarta.

Khoeroni, F., \& Tengah, J. (2018). Problematika Soft Skills.

Laureta, B., Zealand, N., \& College, T. (2019). Encouraging the development of soft skills through play. He Kupu, 6(2), 26-29. Retrieved from https:/ / www.hekupu.ac.nz/article/encouraging-development-soft-skills-throughplay 
Lisnawati, I. (2018). The Professionalism of Indonesian Teachers in The Future. JETL (Journal Of Education, Teaching and Learning). https://doi.org/10.26737/jetl.v1i1.458

Luo, W., Berson, I. R., Berson, M. J., \& Li, H. (2021). Are early childhood teachers ready for digital transformation of instruction in Mainland China? A systematic literature review. Children and Youth Services Review, 120(June 2020), 105718. https://doi.org/10.1016/j.childyouth.2020.105718

Muhmin, A. H. (2018). Pentingnya Pengembangan Soft Skills Mahasiswa Di Perguruan Tinggi. Forum Ilmiah.

Putri, N. W. S., Suryati, N. K., Kartini, K. S., \& ... (2020). Peningkatan Softskill Ict Guru Melalui Pelatihan Penggunaan Microsoft Office Dan Sosial Media. JMM (Jurnal ..., 4(4), 6-9. https://doi.org/doi.org/10.31764/jmm.v4i4.2081

Robbie, I., \& Marsudi, M. (2021). Penerapan Manajemen Kinerja Berbasis 3C (Communication, Collaboration and Creativity) Dalam Membentuk Karakter Pada Guru Paud dan TK di Desa Pendem Kecamatan Junrejo Kota Wisata Batu. Jurnal Pengabdi, 4(1), 13. https://doi.org/10.26418/jplp2km.v4i1.42317

Sofia, A., \& Yulista, A. (2020). Pengaruh Kompetensi Kepribadian terhadap Motivasi Kerja Guru Pendidikan Anak Usia Dini. PAUD Lectura: Jurnal Pendidikan Anak Usia Dini, 3(2), 12-18. https://doi.org/10.31849/paud-lectura.v3i02.3445

Sukamto, Y., \& Pardjono, P. (2017). Pengaruh Kompetensi Guru, Komitmen Kerja Dan Motivasi Kerja Terhadap Kinerja Guru Smp Andalan Di Sleman. Jurnal Penelitian Ilmu Pendidikan, 9(2), 165. https:/ / doi.org/10.21831/jpipfip.v9i2.12917

Sum, T. A., \& Taran, E. G. M. (2020). Kompetensi Pedagogik Guru PAUD dalam Perencanaan dan Pelaksanaan Pembelajaran. Jurnal Obsesi : Jurnal Pendidikan Anak Usia Dini, 4(2), 543. https:// doi.org/10.31004/obsesi.v4i2.287

Sumiyati. (2020). Pelatihan soft skill untuk meningkatkan kualitas dan mutu layanan PAUD di Desa Ngagel,. As-Sibyan Jurnal Pendidikan Anak Usia Dini, 5(1), 31-42. https://doi.org/10.32678/as-sibyan.v5i1.2425

Sutarmanto. (2019). Kompetensi Dan Profesionalisme Guru Pendidikan Anak Usia Dini. Jurnal Visi Ilmu Pendiidkan, 16-31.

Thuneberg, H. M., Salmi, H. S., \& Bogner, F. X. (2018). How creativity, autonomy and visual reasoning contribute to cognitive learning in a STEAM hands-on inquiry-based math module. Thinking Skills and Creativity. https://doi.org/10.1016/j.tsc.2018.07.003

Undang-Undang Republik Indonesia Nomor 20 tentang Sistem Pendidikan Nasional. (2003).

Yuniendel, R. K. (2018). Kontribusi Soft Skill dan Hard Skill dalam Meningkatkan Profesionalisme Guru Pendidikan Agama Islam di Sekolah dan Madrasah. Murabby: Jurnal Pendidikan Islam, 1(1), 48-59. https:// doi.org/10.15548/mrb.v1i1.286

Yusutria. (2017). Profesionalisme guru dalam meningkatkan kualitas sumber daya manusia. Jurnal Curricula, 2(1), 40. https:// doi.org/10.24235/tarbawi.v2i1.2026

Yusutria. (2018). Analisis Mutu Lembaga Pendidikan Berdasarkan Fungsi Manajemen Di Pondok Pesantren Thawalib Padang Sumatera Barat. Ta'dib: Jurnal Pendidikan Islam, vii(2), 84-95. https://doi.org/10.29313/tjpi.v7i2.3833 